\title{
AVALANGHE-HAZARD MAPPING AND ZONING PROBLEMS IN THE ROGKY MOUNTAINS, WITH EXAMPLES FROM COLORADO, U.S.A.
}

\author{
By Jack D. Ives and Misha Plam \\ (Institute of Arctic and Alpine Research, University of Colorado, Boulder, Colorado 80309, \\ U.S.A.)
}

Abstract. Avalanche-hazard mapping as a basis for land-use decision-making was not undertaken systematically in Colorado until 1974. Passage of Colorado House Bill 104I required counties to map areas subject to snow avalanche, landslide, debris flow, and mountain flood at $1: 24$ ooo, and funds were provided. This legislation induced several approaches: work undertaken directly by the Colorado Geological Survey; private contract work; mapping by the Institute of Arctic and Alpine Research (INSTAAR) funded by a NASA research grant. This latter effort produced 37 individual $1: 24$ ooo map sheets of Hinsdale, Ouray, San Juan, and San Miguel counties, San Juan Mountains. This emphasized problems of scale and degree of cartographic accuracy. Swiss, Austrian, and French experience, together with the actual Colorado mapping experience, facilitated further definition of problems facing the Rocky Mountains states, both in terms of resolution of actual mapping problems, and of using such developing experience to influence the decision-making process.

Two mapping attempts are described: (i) development of a combined hazard map for a mountain type area, indicating the difficulties of, and need for, combining hazard assessment of avalanche and other physical processes that frequently overlap; (ii) consideration of avalanche-zoning problems in a wilderness area.

Finally, scale limitations and the need to define rigorously "hazard" are discussed. Definition of hazard must include consideration of recurrence interval, impact pressures in the run-out zone, and limitations of displaying this type of data on available topographic maps, all in relation to types of impact, i.e. to moving or stationary objects in relatively sparsely populated terrane. Additional critical needs facing Rocky Mountains states are itemized: (i) standardized mapping legends for different scales; (ii) establishment of an avalanche cadastre; (iii) systematic reporting of climax events; (iv) development of an historical archive; (v) public awareness; (vi) attention to legal aspects of the avalanche equivalent of the hundred-year flood, and its legal testing.

RÉsumé. Problèmes de la cartographie et du zonage des avalanches dans les Rocky Mountains avec exemples tirés du Colorado, U.S.A. La cartographie du risque d'avalanche comme base des décisions d'aménagement n'avait pass été entreprise systématiquement au Colorado avant 1974. Un article de la loi du Colorado 104I (Colorado House Bill) oblige les comtés à cartographier les zones sujettes à avalanches de neige, glissements de terrain, laves torrentielles et inondations à l'échelle du I : 24000 , et apporte le financement correspondant. La législation permet plusieurs approches: le travail entrepris directement par le Colorado Geological Survey, le travail sous contrat privé, la cartographie par l'INSTAAR financée par une aide pécunière de la NASA. Cette dernière voie a abouti à la rédaction de 37 feuilles individuelles au $1: 24$ ooo concernant les comtés de Hinsdale, Ouray, San Juan, et San Miguel, dans les San Juan Mountains. Ceci a posé des problèmes d'échelle et de degré de précision cartographique. Les expériences suisses, autrichiennes et françaises ainsi que la réelle expérience cartographique du Colorado ont facilité une nouvelle définition des problèmes qui se posent aux États des Rocky Mountains, à la fois pour réaliser la cartographie et pour utiliser l'expérience acquise afin d'influencer les décisions d'aménagement.

On décrit deux essais de cartographie: (i) le développement d'une carte de risques combinée pour une zone type de montagne, indiquant les difficultés et les besoins pour prendre en compte les risques d'avalanches et les autres processus physiques qui s'y superposent fréquemment, (ii) la considération du zonage des avalanches dans un espace sauvage.

Finalement, les limitations par l'échelle et le besoin de définir rigoureusement la notion de "risque" sont discutés. La définition du risque doit comprendre la considération de la périodicité de retour, de la pression d'impact à atteindre dans la zone de dépôt et les limitations inhérentes au report de ce type de données sur une carte topographique utilisable; le tout en relation avec le type d'impact, c'est à dire avec les objets, mobiles ou immeubles dans un terrain relativement peu peuplé. Les besoins supplémentaires critiques qui s'imposent aux États des Rocky Mountains sont recensés: (i) légendes cartographiques standardisées aux différentes échelles, (ii) l'établissement d'un cadastre des avalanches, (iii) le report systématique des événements météorologiques, (iv) le développement d'archives historiques, (v) l'information du public, (vi) l'attention aux aspects légaux de l'équivalent en matière d'avalanches de la crue centenaire, et de son établissement légal.

Zusammenfassung. Karten der Lawinengefährdung und Zonungsprobleme in den Rocky Mountains, mit Beispielen aus Colorado, U.S.A. Bis 1974 gab es in Colorado keine Karten der Lawinengefährdung als Grundlage für Landnutzungsplanungen. Mit dem Colorado House Bill 104I wurden die Landkreise verpflichtet, Gebiete 
mit Gefährdung durch Schneelawinen, Erdrutsche, Verschüttung und Überflutung im Masstab I : 24 ooo zu kartieren; hierfür wurden Mittel bereitgestellt. Diese gesetzgeberische Massnahme führte zu mehreren Aktivitäten: Arbeiten unmittelbar durch den Geological Survey von Colorado; Arbeiten unter privatem Kontrakt; Kartierung durch INSTAAR mit Forschungsgeldern der NASA. Die letztgenannte Unternehmung führte zur Herausgabe von 37 einzelnen Kartenblättern I : 24 ooo der Gebiete von Hinsdale, Ouray, San Juan, und San Miguel, San Juan Mountains. Dabei traten Probleme hinsichtlich des Masstabs und der kartographischen Genauigkeit auf. Schweizerische, österreichische und französische Erfahrungen erleichterten zusammen mit denen, die unmittelbar in Colorado gewonnen wurden, die Problemstellung für die Staaten der Rocky Mountains, sowohl hinsichtlich der eigentlichen Kartierung und ihrer Genauigkeit wie auch der Nutzung der gewonnen Erfahrung für Entscheidungsprozesse.

Zwei verschiedene Kartierungsansätze werden beschrieben: (i) Entwicklung einer kombinierten Gefährdungskarte für gebirgige Gegenden; dabei zeigen sich einerseits die Schwierigkeiten bei der Kombination der anzunehmenden Gefährdung durch Lawinen und durch andere physikalische Vorgänge, die häufig zusammen auftreten, andererseits die Notwendigkeit einer solchen Kombination; (ii) Einteilung in

Schliesslich werden Masstabsabgrenzungen und die Notwendigkeit zur scharfen Definition des Begriffs "Gefährdung” diskutiert. Diese Definition muss die Zeitintervalle des Wiederauftretens, den Auftreffdruck in der Auslaufzone und die Grenzen der Darstellbarkeit solcher Daten in vorhandenen topographischen Karten berücksichtigen, und dies alles im Zusammenhang mit der Art des Aufpralls, d.h. mit beweglichen oder festen Objekten in einem relativ dünn bevölkerten Gebiet. Als zusätzliche wichtige Bedürfnisse im Hinblick auf die Staaten der Rocky Mountains werden aufgeführt: (i) Standardisierte Kartenlegenden für verschiedene Masstäbe; (ii) Aufbau eines Lawinenkatasters; (iii) Systematische Meldung wichtiger Ereignisse; (iv) Entwicklung eines historischen Archivs; (v) Öffentlichkeitsarbeit; (vi) Beachtung juristischer Gesichtspunkte für die Einschätzung der Lawinengefährdung.

\section{INTRODUCTION}

Avalanche-hazard mapping as a basis for land-use decision-making, while conducted on a cursory basis for many years (Fuchs, I955; Frutiger, 1964) and while often discussed in the context of disasters that accompanied the mining boom period, 1870-1920 (Armstrong, 1976, 1977), was not subjected to any systematic approach until after the passage of Colorado House Bill (H.B.) 104I in 1974. This bill immediately inserted assessment of natural (geologic) hazards as a factor in Colorado land-use decision-making. One section of H.B. I04I requires individual counties to map areas subject to a variety of "geologic" hazards, including snow avalanche, landslide, debris flow, and mountain flood. These and associated hazardous phenomena are described for legal purposes by the Colorado Geological Survey (CGS) (Rogers and others, I974). The mapping scale was formally set at I : 24 ooo to conform with the USGS topographical survey base, the only base available, and state funds were provided, either directly through the CGS, or indirectly via the county governance authorities, to facilitate the mapping process.

This paper will present a brief outline of avalanche mapping and zonirig progress prior to 1974 in Colorado, and will discuss developments subsequent to the passage of H.B. 1041. The latter will include description of efforts made to provide more useful maps, together with their limitations, efforts to increase public awareness and to define more clearly the many problems still remaining. Examples of some of the available maps from Colorado are discussed.

It is contended that the descriptions of avalanche mapping and zoning in Colorado can be used in the context of the entire Rocky Mountains region. The only qualification of this statement is that Colorado, with the exception of certain site-specific studies, is in a much more advanced position than the other Rocky Mountains states.

\section{Avalanche-HazARD KNOWLedge AND APPlications PRIOR TO 1974}

This section is treated only in brief. The mountain mining boom period of approximately 1870-1920 saw the rapid development of scattered populations in many of the State's mountain areas. Ms B. R. Armstrong is completing the pioneering task of accumulating material relating to this period, especially for the San Juan Mountains, and has already demonstrated 
the availability of data that should form a critical base for any future state-wide avalanche cadastre (Armstrong, I 976, I 977). Suffice it to say that, on the basis of grim human experience (98 deaths in San Juan County alone), much understanding of the characteristics of avalanching snow was acquired during this early period. Precautionary measures were improvized, including defense structures, use of explosives, and initial, although not enacted, calls for land-use zoning. With the collapse of the mining boom and associated drastic reduction in mountain population, the problem of avalanche hazard to life and property dropped into temporary oblivion. Nevertheless, sporadic fatalities continued to be reported as in I924, 1926, I936, I951, and 1958 (Armstrong, r976, I977).

Beginning as recently as the 1950's, increased development of, and use of, state mountain highways re-opened the problem of response to avalanche dangers. Responsibility lay principally with the State Department of Highways and with the U.S. Forest Service (Judson, 1970), resulting in the first attempts at systematic collection of avalanche-event data in terms of highway-crossing points. The latter, through an invaluable borrowing of Swiss experience, produced the first avalanche road map of the State's most endangered areas (Frutiger, 1964).

But it required the enormous growth in Colorado winter recreation dating from the late I960's, and the rapid spread of second homes that paralleled it, for the real and potential urgency of the problem to come more fully into focus. The succession of mushroom-growth resort towns beginning with Aspen and Vail, but spreading to Steamboat Springs, Dillon, and Telluride, and continuing to accelerate with Crested Butte and other centers, already created serious and specific problems, but on an essentially local scale prior to i974. Thus avalanchehazard consultants began work in the vicinity of Vail, and in other areas, and the Colorado Geological Survey, supported by many other groups and individuals, began a campaign to alert the public and especially the State legislators, in the early 1970's. This was paralleled by an increased attack on avalanche-forecasting problems by the U.S. Forest Service (USFS), Rocky Mountain Range and Experiment Station, Fort Collins (Judson, i 970). It is perhaps of special interest that the U.S. Department of the Interior, Bureau of Reclamation, through a research contract with the Institute of Arctic and Alpine Research (INSTAAR), University of Colorado, in touching off a major study of avalanche-forecast problems in relation to winter cloud-seeding experiments, laid the foundation for the State's currently largest avalanche and natural-hazard mapping project (Armstrong and Ives, 1976; Ives and Bovis, 1978). This contract also facilitated the association of a large research grant (NASA Office of University Affairs PY-NGL-06-003-200, to Ives, INSTAAR) that also exerted an impact upon the events leading up to the passage of H.B. ro41. Thus occurred the first, albeit preliminary, mapping of avalanche and mudflow run-out zones in the developing resort area of Vail and vicinity (Krebs, unpublished) which, however, led almost immediately to major changes in the building code and the land-acquisition program of the township of Vail (Ives and Krebs, 1978). Along similar lines, land-use decision-making was influenced in San Juan, San Miguel, and Ouray counties. In this context, particular reference is made to Telluride and to the township of Ophir where, at least temporarily, a major development project scheduled for the Spring Gulch fan was halted (Ives and others, 1976). Avalanche atlases were developed for the highway sections of San Juan and Ouray counties (Miller and others, 1976; Armstrong and Armstrong, 1977). A conference held at Vail in November 1973, sponsored by INSTAAR under the auspices of the NASA-PY grant, and aided by collaboration from CGS and USFS (Fort Collins), attempted to bring attention to banks, insurance agencies, land owners, officials, and members of the public the increasingly critical nature of the avalanche problem in Colorado. This period of somewhat unorganized, incidental, and piece-meal activity by federal and state government agencies, universities, private consultants, and individuals culminated in 1974 with the passage of H.B. I041. This landmark legislation, sponsored by Representative R. Lamm, later to become Governor of the State, placed Colorado in the forefront of the federation in terms of its recognition of the problem and its legislative stand. 
House Bill io4I AND its consequences, I 974-79

Legal and constitutional complexities that beset Swiss attempts to grapple with the problem of avalanche zoning have been described by Frutiger (1980). As with avalanche research, so with legal issues, Colorado is a decade or so behind Switzerland and other Alpine countries. This is not necessarily a disadvantage, since the problem in Colorado has not yet reached Alpine proportions; thus a great advantage can still be taken of the Alpine experience before continuing construction progressively narrows the range of land-use decision-making options. H.B. I04I, in part, requires individual counties to produce I : 24 ooo scale maps of areas subject to "geologic hazards". * It goes on to define a geologic hazard as "a phenomenon that is so adverse to past, current and foreseeable construction or land uses as to constitute a significant hazard to public health and safety, or to property". This rather vague wording indicates legal and constitutional problems relating to property rights and public responsibilities that makes intriguing reading in the context of Frutiger's discussion of similar problems in Switzerland (Frutiger, I980). More rigorous definition was not to be expected, in part because of the legal and constitutional problems alluded to here, and in part because of the near absence of information on extent of run-out zones, degree of impact pressures, recurrence intervals, and hazardous events of climax and lesser magnitudes, as well as the inadequate topographical map base.

The intent of H.B. I04 I was to place in the hands of county planning officers a tool for use in controling the hitherto virtually uncontroled land speculation and construction in hazardous areas. Thus it was recognized that the topographical map scale of I : 24 00o, and the relatively poor quality even at that scale compared with maps of similar scales of the Alpine countries, was not adequate for site-specific avalanche survey as a basis for construction or avoidance of construction. The approach taken, therefore, was the production of $1: 24000$ scale maps that would be considered as a reconnaissance tool only. This at least would enable the planning officer, faced with an application for a building permit for a parcel of land that appeared to be in proximity to a hazardous area, to respond. Thus, such a permit need only be issued if the applicant, through much more detailed site survey, were able to provide proof of the safety of the site in relation to the proposed building-design criteria.

Passage of House Bill I04I in I974 touched off three separate, but by no means conflicting, approaches. First, private consultants undertook specific studies for particular county and township areas. Secondly, the Colorado Geological Survey developed a state-wide effort concentrating on avalanche-hazard areas where the need seemed most urgent (Mears, 1976, 1979). "The intent ... was to select and map those areas of present or expected intensive development activity where avalanche hazards were known to exist. Final selection(s) ... were made after consultation with the U.S. Forest Service, State agencies, local governments, and knowledgeable citizens" (Mears, 1979, p. 33). The I 5 maps have been published at the reduced scale of $\mathrm{I}: 50000$ and are available in open file at I : 24000 from CGS. They, in effect, are an application and adaptation of the Swiss approach, which defines three basic zones in order of decreasing hazard: red, blue, and white (Frutiger, 1970).

The third approach, perhaps more typical of a university research institute, placed emphasis upon research problems, including cartographic representation, and the challenge of showing multiple hazards, often overlapping, on one map, or one mapping system. Having a geographical philosophical base, it furthermore tackled the problem from a county-wide, or regional, mapping point of view (Ives and Bovis, 1978). Nevertheless, this approach did include provision for fulfilling the H.B. ro4I requirements for San Juan, San Miguel, Ouray, and Hinsdale counties, and provided much practical advice for the relevant county authorities.

* "Geologic hazards": for a number of reasons (cf. Ives and Bovis, 1978, p. 187-88) the term "natural hazards" is preferred and is used in this paper. It more readily translates into the widely accepted French and German terms risques naturels and Naturgefahren, respectively. 
Three sets of maps, each consisting of 37 sheets, scale I : 24 ooo, were produced and made publicly available in a very short space of time as open-file material in the relevant county offices and at the University of Colorado (Ives and Bovis, 1978; Bovis and others, unpublished $[\mathrm{a}],[\mathrm{b}],[\mathrm{c}])$. Of great concern was demonstration of the need for adoption of a standard mapping legend, or legends, for the State as a whole (an objective not yet achieved), initial development of three sets of maps and legends (geomorphic hazards map, avalanche-hazards map, combined hazards map). It was also assumed, in contrast to other work on this scale (e.g. Mears, r 976, 1979), that attempts to delimit Colorado equivalents of the Swiss red and blue zones (Frutiger, 1970) ran the risk of spurious accuracy. Finally, the project was conceived as one of on-going research, in terms of study of the physical processes, collection of historical data, cartographic expression, legend refinement, and public awareness. Thus more recent developments have been: production of a combined hazards prototype map (Dow and others, unpublished); construction of an avalanche map for a back-country wilderness area (Plam, unpublished); and incorporation of both these into a mountain-area environmental atlas (Ives and others, 1979; Baumgartner, in press). In addition, attempts were made to study the suitability of satellite imagery scanning and computorized mapping of hazardous areas which have so far understandably met with only partial success. Nevertheless, these attempts show promise, especially with the future availability of third-generation LANDSAT imagery (Knepper, 1977; Waterman, 1978).

\section{ON THE NEED FOR AN INTERDISGIPLINARY AND MULTI-AGENCY APPROACH}

Aulitzky (1974) has argued that avalanche-hazard mapping per se is subject to serious limitations. This is because avalanche paths are frequently the sites of mountain torrents (Wildbach), mud-flows, and landslides. Thus, the development of a zoning plan for avalanche hazard, and especially the construction of defense structures, may exacerbate problems relating to overlapping or proximate geomorphic hazards. This philosophy has very much influenced the INSTAAR approach. Similarly, avalanche-zone study alone cannot be done effectively without input from botanists, foresters, engineers, climatologists, geographers, geologists, historians, anthropologists, and so on. This is especially true in the Colorado Rockies where documentary data of former events, especially when compared with that available for the Alpine countries, are so scarce, and where "silent witnesses" (the Stumme Zügen of Aulitzky (1973)) need careful field interpretation.

A similar line of argument supports the justification for an interagency approach. Thus, a large proportion of Colorado's mountain land, as with most mountain states, is administered by federal agencies; and university research is sometimes freer of bureaucratic constraints to facilitate pursuit of unconventional approaches; finally, a state agency is probably the best type of institution for designation as the lead agency such that, in collaboration with all the other types of institution and individuals, continuity can be maintained, as well as effective application, and archival support.

Some examples of potential and actual error deriving from rushed work on a narrow disciplinary basis, and problem-solving efforts, are described below to support this general plea. The examples include actual mapping as well as hazardous events on state highways.

\section{(i) Telluride Quadrangle, USGS (Luedke, r976)}

When compared with the INSTAAR map on the same scale ( $1: 24000$ ) and quadrangle (each produced without knowledge of the other!), the USGS map was seen to have omitted I 5 major avalanche paths which had been sufficiently active during the mining boom period to have resulted in extensive loss of life and property. That such a map was produced by such an eminent and respected authority during a period of high-pressure land speculation was potentially calamitous. Through the good offices of the USGS Denver Federal Center 
Central Environmental Geology Branch, a revised version of the Luedke map is now in production as a joint undertaking (Armstrong and Carrara, in press). At least part of the problem in this example was lack of forestry and botanical input, and especially absence of detailed historical research such as that carried out by Armstrong (1976, 1977).

(ii) Camp Bird area, Ouray County, snow-avalanche hazard zones (CGS-Mears, 1979, p. 53)

This map, drawn at I : 24000 and published at I : 50 ooo provides an excellent coverage for the Camp Bird area and approaches with one important exception. Armstrong's (1977) historical study, together with remote sensing using NASA color IR LANDSAT underflight imagery, revealed a major avalanche path that not only threatens the main camp area, but which caused extensive destruction of property and loss of one life, trapping nine others in I906. The same path ran again in 1974, stopping a few meters from the mill (Armstrong 1977). This is entirely missing from the CGS map.

(iii) Incident at Brooklyns avalanche paths, San Juan County, 9 February 1976 (Armstrong, unpublished)

Despite provision of the San Juan County avalanche atlas (Miller and others, 1976) and historical studies (Armstrong, I976), in addition to general snow and avalanche research based on Silverton (Armstrong and Ives, I976; Bovis, I977), State Department of Highways winter-management practices still resulted in most winter highway closures occurring subsequent to significant avalanche activity. Thus, on 9 February 1976, two buses and several private automobiles found their forward progress blocked by avalanche debris. To make matters worse, retreat was subsequently cut off. Finally, another avalanche hit the line of vehicles; it was remarkable that only one minor injury was sustained. Nevertheless, the ensuing search and rescue can only be described as a shambles. Passengers from the trapped vehicles set out on foot for Silverton; no one at the accident site knew how many people had left; highway crews suffered several mechanical failures, and so on. This all occurred amidst one of the most severe cycles of avalanching during the period $1970-78$, and the mountain weather forecast, liberally ahead of time, had clearly indicated heavy and rapidly accumulating snow-fall.

As no loss of life had occurred, it was considered diplomatic that a full report on this incident not be presented to the State authorities until a significant amount of time had elapsed (Armstrong, unpublished). But when submission of the report was made, one senior State official passed the incident off as a unique occurrence!

\section{(iv) East Riverside avalanche path, Ouray County (Armstrong and Armstrong, unpublished)}

The East Riverside avalanche path has long been recognized, at least amongst certain sectors of the public, as one of the worst "killers" in the State (Frutiger, r 964; Armstrong and Armstrong, 1977). The two most recent deaths involved Department of Highways snow-plow operators in 1970 and 1978 . It is perhaps tragically ironic that INSTAAR's covering letter to the Armstrong report on the Brooklyns incident, submitted days before the second death, contained urgent references to the high degree of hazard to which plow operators were submitted under the existing operational procedures! This incident resulted in a public outcry from the San Juan Mountains people, a demand for an avalanche shed, and a hearing with the Governor. During the hearing, it became apparent that the Governor's questions on frequency and magnitude of East Riverside avalanche events could not be answered by the relevant State officials. The answers were eventually provided by Ms J. Jorgensen of the Ouray Plain Dealer (personal communication from Ms Jorgensen to B. R. Armstrong, 1978), who presented to the Governor her personal copy of a publication that contained all the available data (Armstrong, 1977).

The intent of relating the previous two examples is absolutely not to lay blame, since there is none to lay, but to indicate the magnitude and seriousness of the task, so clearly evidenced 
in the Alpine countries, of "getting the message across". Significant changes in winter highway operations were being made between 1977 and 1979 . The decision to build an avalanche shed or tunnel at the East Riverside site is still pending.

\section{(v) Combined hazards map (INSTAAR) (Dow and others, unpublished)}

This I : 24 ooo scale map represents the most recent INSTAAR effort to grapple with cartographic problems of representing multiple hazards on a single map at this scale. It will be published separately with an accompanying text; it formed the basis for a Master's dissertation accepted by the University of Colorado (Dow, unpublished). The original intent was to use as basic data for the cartographic experiment the first-generation black-and-white map series from the Silverton vicinity, San Juan Mountains (Ives and Bovis, 1978). Once topographic map inaccuracies were detected, and the cartographic incompatibility* of the avalanche-hazards and geomorphic hazards maps was indicated, an alternate (Monarch Lake Quadrangle, Front Range) was selected for this experiment. An advantage of this decision was that it combined the specific experiment with the recently established mainline direction of the INSTAAR/NASA-PY project-the production of an environmental atlas for the Indian Peaks Wilderness Area (Ives and others, I979; Baumgartner, in press).

Two major cartographic difficulties had to be resolved before the Monarch Lake combined hazards map could be completed: first, clarity of avalanche-path expression for superimposition upon the geomorphic hazard lineaments; secondly, delineation and clear separation of hydrographic features, especially in those areas where avalanches run out across frozen winter-lake surfaces. These problems were at least partially solved by use of a fine white stipple for avalanche-path overlay, and by hatching lake-boundary lines where avalanches are superimposed.

It could be argued that such a multi-colored prototype map will not be economically feasible in Colorado in the near future. In this case, the first-generation black-and-white multiple map series of the San Juan Mountains (Ives and Bovis, I978), and the CGS approach which basically derives from it (Mears, I979), may be seen as eminently satisfactory. Nevertheless, this argument side-steps one of the objectives of attempting the multi-colored single map: that of influencing the public, legislators, and planners, as well as developers and speculators. Over the last 20 years the North American public at large, and certainly many special sectors of that public, have come to think in color, whether it be through the media of television, movie, amateur photography, magazine, or map; even newspapers are producing more and more color work. We believe, therefore, that efforts of this type have a critical role to play.

\section{(vi) Specialized Wilderness Area avalanche map (Plam, unpublished)}

The problems of mapping back-country areas may be irresolvable, considering costs and large numbers of small avalanche paths (Mears, 1979). It is the small avalanche, virtually unmappable at I : 24 ooo that will account for most accidents amongst unwary cross-country skiers (Perla and Martinelli, 1976). Thus back-country avalanche protection and warning may be handled most effectively through development of a general education and information program aimed at the individual cross-country skier and over-snow vehicle enthusiast. Nevertheless, the Monarch Lake area, lying within the newly established Indian Peaks Wilderness Area, has the potential of becoming a heavily used ski-touring center with designated trails, huts, and other facilities. In this kind of situation, we believe that an avalanche-hazard map may be of critical importance in terms of avoidance, as well as search

\footnotetext{
* This was partly due to the quality of the topographic base and partly to inaccurate transfer of data to map, also related in part to the former.
} 
and rescue behavior, and lay-out of trail network. But there is another, and perhaps more important consideration of a political nature. This relates to the original attempts to establish the Wilderness Area, and subsequently to fix its north-western boundary.

Initially, the U.S. Forest Service had designated much of the Arapaho Creek valley as land suitable for logging. The associated steep slopes were considered advantageous in this regard, since they would facilitate transfer of felled trees to the valley floor. However, supporters of the Indian Peaks Wilderness Bill argued for inclusion of this valley within the protected area. Presentation of Plam's preliminary version of the avalanche-hazard map (Fig. I) at public hearings had a major impact on the decision-making process. The legend included the category "potential avalanche hazard" determined on the basis of snow-pack stability in the

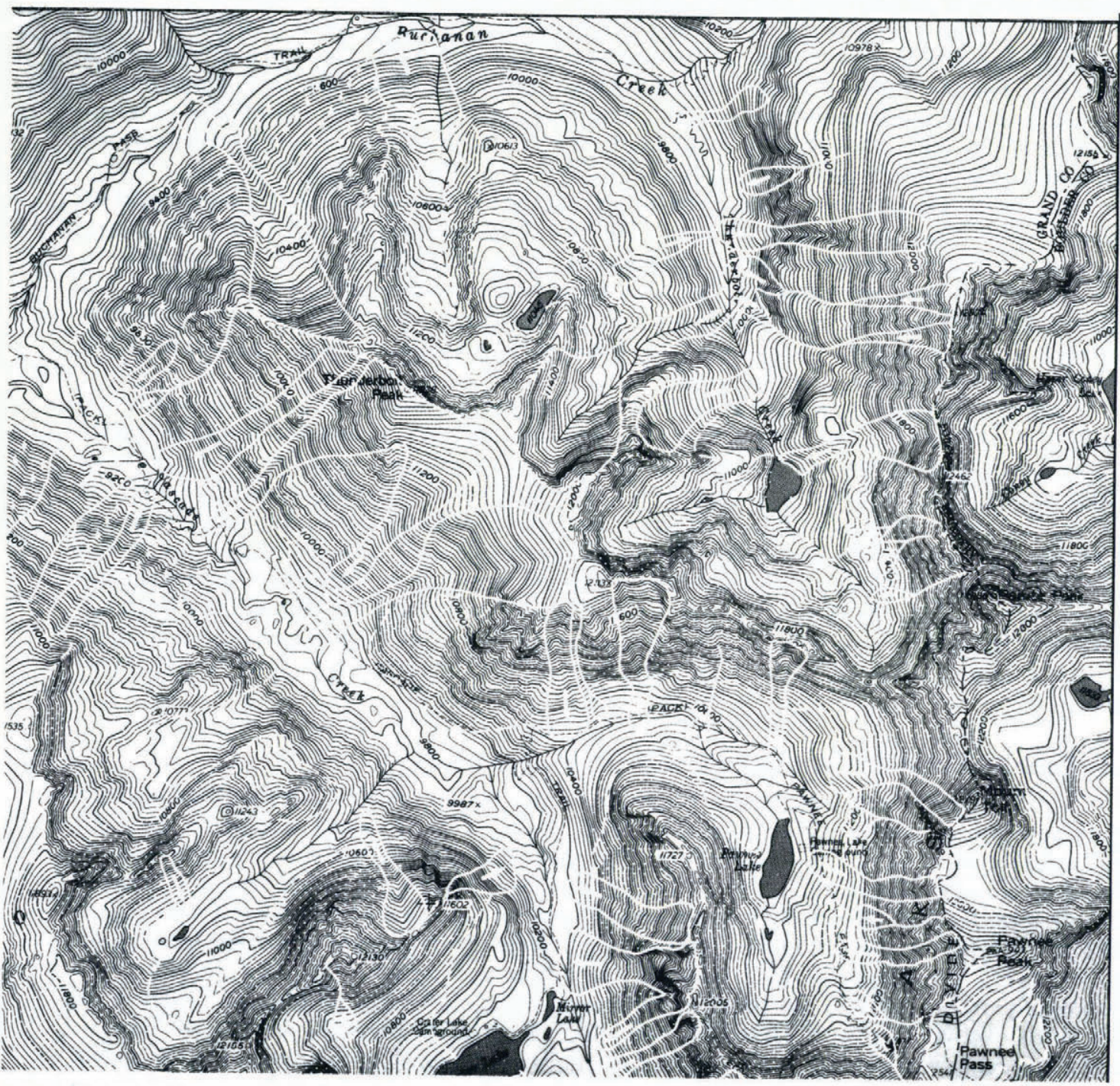

Fig. $\boldsymbol{I}$. Section of avalanche-hazard map by M. Plam. The map was drawn at a scale of $1: 24$ ooo using the USGS topographical map (Monarch Lake Quadrangle) as a base. It represents part of the north-west section of the Indian Peaks Wilderness Area, Colorado Front Range, U.S.A.

1. Active avalanche-confined path. 2. Active avalanche-unconfined path. 3. Potential avalanche slope. 
event that deforestation would occur. This would indicate that logging (or forest fire) would likely cause initiation of many new avalanche paths on slopes with gradients characteristic of the area in question, and especially in the upper part of the valley close to the Continental Divide. Thus, both the principle of inclusion within the proposed Wilderness Area and final precise boundary designation will have been influenced by this map.

Another feature of the mapping legend is the designation of two run-out sub-divisions on certain avalanche paths. Based upon vegetation analysis, it is considered feasible, even at the I : 24 ooo scale, to make such a separation with avalanche occurrence evaluated at I in ro years for the main area, and at $\mathrm{I}$ in 50 years for the outer area.

Finally, the introduction of a "potential avalanche hazard" category, based upon consideration of the stabilizing influence of an unbroken forest cover, acknowledges the importance of the Alpine countries' experience and the close regulation of high-elevation forests there.

\section{Problems of topographical base scales in Colorado}

Relatively undeveloped areas, such as the Colorado Rocky Mountains and surrounding areas as compared to the Alps, require three forms of avalanche mapping, with the attendant need to solve specific base-map scale problems.

\section{(i) Highways and communication lines}

For identification of the problem, these basically elongate areas, or narrow zones, can be handled at a scale of approximately $1: 25000$ (in the U.S.A. this, of course, becomes I : 24 ooo automatically). The pioneer example is the work of Frutiger (r 964$)$; more recent examples include LaChapelle (1974-75), Miller and others (1976), and Armstrong and Armstrong (1977). However, if the relevant authorities ever proceed beyond general identification to construction of defense structures, the base-scale requirement will be $\mathrm{I}:$ io ooo or I : 5 ooo.

\section{(ii) Mining industry activity}

Following the mining industry slump of the early twentieth century, there has been a recent resurgence. As these non-renewable resources increase in scarcity and value, this resurgence will likely accelerate. A good example of major potential activity is Climax Molybdenum's plans for the Crested Butte area where, for instance, preliminary design places a railway line in contact with more than a dozen avalanche paths. In any event, mining projects require engineering site scales of $I: 5000$ to $I: 2000$, especially if avalanche protection will be required. This type of requirement will always be a specialized engineering site issue and in no way related to regional scale needs.

\section{(iii) Ski-ing, general tourist development, and county planning}

This category can be handled on a reconnaissance scale of $I: 24000$, if the basic purpose is avoidance of avalanche-prone areas and general warning. Colorado's primary current need falls into this category, and the I : 24 ooo scale examples discussed in this paper, if standardized, will more or less satisfy this need. However, it is emphasized that such a stipulation is only supportable in regiens like the Rocky Mountains so long as there is an abundance of "unused" land. It would be completely irresponsible, however, to assume that this abundance of land will remain unchanged. It is more likely to change very quickly; we may be much closer to the Alpine situation than we realize. Once protecting structures are required, and once several sub-divisions of avalanche run-out zones become desirable, the requirement for a good I : Io ooo topographical base becomes critical. It would seem highly 
desirable, therefore, that some work on this scale be initiated immediately. Then the development of methods, expertize, and studies of legal and property right implications, of avalanchehazard mapping on the Swiss and Austrian scales* can proceed before Colorado (and neighboring states) finds itself in a situation comparable to the Alps of the 1950's and 1960's.

\section{Problems Related to map appligations}

With minor exceptions, and considering the relatively poor quality of many of the I : 24 ooo map sheets, it would appear that there is currently no adequate topographic base, nor are there avalanche-occurrence and characteristics data, within the Rocky Mountains area, to support more than the generalized mapping of avalanche paths as indicated by Ives and Bovis (1978). Moreover, the Swiss and Austrian experience serves to indicate the need for establishment of regional avalanche (and other natural hazard) cadastres. Furthermore, these need to be interrelated with land-holding registers before effective passive control of land-use developments can be achieved. Thus, systematic archiving of future climax events, combined with historical research and documentation, should be initiated by a central state agency. Additional legislation is also needed as a basis for future hazard-zone sub-division. The legal concept of the "hundred year flood", now firmly established in United States land-use regulations, could reasonably be tested and applied. The use of a recurrence interval in excess of Ioo years could well be challenged, to echo Frutiger (1980), in discussing the Swiss Alps. How can a greater recurrence interval be justified when other statistically more probable hazards to life and property are apparently acceptable? The great legal and scientific complexities of establishing the Swiss equivalent of the "blue zone" will await further progress in knowledge of impact pressures and recurrence intervals in Colorado where climatic differences, inferred by use of the expression "radiation snow climate" may render direct application of Alpine methods somewhat uncertain. However, the need for resolving these problems is close upon us as gently sloping land is used up and development, with attendant defense structures, becomes more common. In addition, the red, blue, white color scheme of Switzerland would be better replaced by the traffic-light scheme of Austria (Aulitzky, 1974). There is also the need for recognition of the problems of multiple and overlapping hazards, and winter and summer sets of processes.

Finally, there remains the problem of public awareness and response. The Colorado Avalanche Warning Program of the U.S. Forest Service has done much to alert the public to avalanching in recent years (Judson, I975; Williams, 1978) and the recently published Avalanche handbook (Perla and Martinelli, I976) is another great asset. But the problem remains and an anecdote from Ophir, San Miguel County, is used to illustrate this.

On presenting the first draft of the Spring Gulch fan run-out zone map to the citizens of Ophir in January 1975, Ives and Bovis met a series of conflicting responses: (I) pleasure that the map should protect the township from unwanted "affluent" development on the fan; (2) concern that the mayor's house lay inside the limits defined as hazardous - "could we just move the line $0.5 \mathrm{~cm}$ to clear the house?"- "Of course, but do you think that will reduce the risk?" The following summer, in company with Messrs Armstrong, Frutiger, LaChapelle, Mears, Shearer, and others, construction of a new house was seen to be under way in an area designated as subject to wet spring avalanches. In answer to questions, the young builder explained that, since it was on stilts avalanches would run underneath it. As I introduced my colleagues, the builder's face paled since he recognized their names from our report. LaChapelle responded with gusto- "My advice to you, my friend, is to rent the house out when you have finished it, and go back to college for a higher degree".

\footnotetext{
* Similarly, as the necessary topographical base becomes available, generalized regional planning maps at I : 50000 or, preferably, I : I00 000, are worthy of development.
} 
The most recent step on the Ophir scene is that some of the very people who pleaded for avalanche-hazard mapping as a device to stop a development corporation, are now challenging the county planning office. They charge the need for exceptions because of the lack of finality in the original run-out zone delimitation (personal communication from Ms J. McGowan, County Planning Officer, r979).

\section{Conclusions AND RECOMMENDATIONS}

The State of Colorado mountain land and similar terrane in adjacent states may be regarded as about a decade or more behind the Alpine countries, both in its avalanche-hazard mapping research and in its requirements for such knowledge in terms of land-use decisionmaking pressures. Nevertheless, the gap may be closing more rapidly than is generally realized.

A series of steps, recommended below, would do much to close the research gap and so avert future possible catastrophes and large expenditures of public monies in construction of defense works.

I. The creation of an interdisciplinary and inter-agency approach utilizing all sources of data and expertize under the auspices of a State agency, as the lead agency.

2. Recognition of the value of studying and mapping all natural hazards under a single program, and not avalanche hazards in isolation.

3. Adoption of standard state-wide hazard legends.

4. Initiation of I : ro ooo scale topographic mapping, at least in selected areas where rapid development is presently occurring in the vicinity of hazardous processes.

5. Production of small-scale maps covering the entire U.S.A. or at least the mountain west, to provide an overview of areas of concentrated mountain hazard.

6. Systematic attempt to define "hazard" in terms of recurrence intervals, impact pressures, and various categories of "targets" such as humans, buildings, and moving objects.

7. A fuller and concerted effort to alert the public, and especially insurance companies, building and loan corporations, and banks.

8. Research into legal aspects of natural hazards and land-use decision making.

9. Development of a state-wide natural hazard cadastre with similar methods and objectives to the Swiss Avalanche Cadastre.

I0. Provision of more funds for basic snow and avalanche research, including collection and archiving of historical data. This should be extended to embrace other mountain hazards.

\section{Acknowledgements}

The large amount of work upon which this paper is based (1970-79) requires acknowledgements to far too many people to make individual reference practical. However, the INSTAAR work has depended primarily upon NASA-PY Office of University Affairs grant number NGL-o6-003-200 to the first author, 1973-79, and Bureau of Reclamation Contract No. 14-06-D-7155. Mr J. Vitale and Dr A. Kahan of NASA and the Bureau, respectively, have contributed far more than their official roles required. Very many graduate students and research associates participated in various stages of the work; principals are B. R. and R. L. Armstrong, Dr M. J. Bovis, P. E. Carrara, V. M. Dow, A. I. Mears, Dr P. V. Krebs, Dr H. Kienholz, and Dr D. H. Knepper. Consultants included Drs E. R. LaChapelle, M. Mellor, W. F. Weeks, H. Frutiger, P. A. Schaerer, M. Martinelli, J. Rold, and Professors H. Aulitzky 
and B. Messerli. Very many individuals, inhabitants of the San Juan Mountains, have provided invaluable moral support and historic data. Special thanks are due to the Department of Highways' staff at Silverton and Durango, and the County Planning Offices of San Juan, San Miguel, and Ouray counties.

B. R. and R. L. Armstrong read through an early draft of this paper and made many valuable suggestions.

\section{REFERENGES}

Armstrong, B. R. 1976. Century of struggle against snow: a history of avalanche hazard in San Juan County, Colorado. University of Colorado. Institute of Arctic and Alpine Research. Occasional Paper No. 18.

Armstrong, B. R. 1977. Avalanche hazard in Ouray County, Colorado, 1877-1976. University of Colorado. Institute of Arctic and Alpine Research. Occasional Paper No. 24.

Armstrong, B. R. Unpublished. Report on Brooklyns Avalanche incident, 9th Feb. 1976. [Written at Institute of Arctic and Alpine Research, University of Colorado, 1978.]

Armstrong, B. R., and Armstrong, R. L. 1977. Avalanche atlas, Ouray County, Colorado. University of Colorado. Institute of Arctic and Alpine Research. Occasional Paper No. 25.

Armstrong, B. R., and Armstrong, R. L. Unpublished. Report on avalanche activity, East Riverside, Ouray County, Colorado. [Written at Institute of Arctic and Alpine Research, University of Colorado, 1978.]

Armstrong, B. R., and Carrara, P. E. In press. U.S.G.S. special map, avalanche hazard, Telluride Quadrangle,

San Miguel County, Colorado.
Armstrong, R. L., and Ives, J. D., ed. 1976. Avalanche release and snow characteristics, San Juan Mountains, Colorado. University of Colorado. Institute of Arctic and Alpine Research. Occasional Paper No. 19.

Aulitzky, H. 1973. Berucksichtigung der Wildbach und Lawinen gefahrengebiete als Grundlage der Raumordnung von Gebirgslandern. (In Ioo Jahre Hochschule für Bodenkultur, Wien, IV(2), p. 81-1 13.)

Aulitzky, H. 1974. Endangered Alpine regions and disaster prevention measures. Strasbourg, Council of Europe. (Nature and Environment Series, 6.)

Baumgartner, R. In press. Landscape maps as an aid to management of scenic mountain areas. [Paper presented at conference: Our national landscape. A conference on applied techniques for analysis and management of the visual resource, Lake Tahoe, Nevada, 1979.]

Bovis, M. J. 1977. Statistical forecasting of snow avalanches, San Juan Mountains, southern Colorado, U.S.A.

Fournal of Glaciology, Vol. 18, No. 78, p. 87-99.
Bovis, M. J., and others. Unpublished [a]. Natural hazards of Ouray County, Colorado, by M. J. Bovis [and 7 others]. [Institute of Arctic and Alpine Research, University of Colorado, report to Ouray County Planning Commission, 1976. NASA-PY Grant No. NGL-o6-0o3-200.]

Bovis, M. J., and others. Unpublished [b]. Natural hazards of San Juan County, Colorado, by M. J. Bovis, R. H. Summer, M. Squier, D. H. Knepper, Jr, and J. D. Ives. [Institute of Arctic and Alpine Research,
University of Colorado, report to San Juan County Planning Commission, 1976. NASA-PY Grant No. NGL-06-003-200.]

Bovis, M. J., and others. Unpublished [c]. Natural hazards of San Miguel County, Colorado, by M. J. Bovis [and 5 others]. [Institute of Arctic and Alpine Research, University of Colorado, report to San Miguel County Planning Commission, 1976. NASA-PY Grant No. NGL-o6-0o3-200.]

Dow, V. M. Unpublished. Cartographic analysis and development of legend and prototype map of multiple geomorphic hazards. [M.A. thesis presented to University of Colorado, 1979.]

Dow, V. M., and others. Unpublished. Map of combined mountain geomorphic hazards (Monarch Lake Quadrangle, Colorado, 7.5 minute series), by V. M. Dow, H. Keinholz, and M. Plam. [MS., 1979.]

Frutiger, H. I964. Snow avalanches along Colorado mountain highways. U.S. Dept. of Agriculture. Forest Service. Research Paper RM-7.

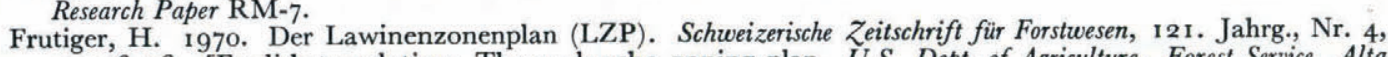
p. 246-76. [English translation: The avalanche zoning plan. U.S. Dept. of Agriculture. Forest Service. Alta Avalanche Study Center Translation No. 1 I, 1970.]

Frutiger, H. 1980. History and actual state of legislation of avalanche zoning in Switzerland. Fournal of Glaciology, Vol. 26 , No. 94 , p. $313-24$.

Fuchs, A. I955. Avalanche conditions and avalanche research in the United States. U.S. Snow, Ice and Permafrost Research Establishment. Report 29.

Ives, J. D., and Bovis, M. J. 1978. Natural hazards maps for land-use planning, San Juan Mountains, Colorado, U.S.A. Arctic and Alpine Research, Vol. 10, No. 2, p. 185-212.

Ives, J. D., and Krebs, P. V. r 978 . Natural hazards research and land-use planning responses in mountainous terrain: the town of Vail, Colorado, Rocky Mountains, U.S.A. Arctic and Alpine Research, Vol. 10, No. 2, p. $213-22$.

Ives, J. D., and others. 1976. Natural hazards in mountain Colorado, by J. D. Ives, A. I. Mears, P. E. Carrara, and M. J. Bovis. Annals of the Association of American Geographers, Vol. 66, No. 1, p. 129-44.

Ives, J. D., and others. I979. Indian Peaks Wilderness Area environmental atlas (Colorado Front Range), by J. [D.] Ives, R. Baumgartner, M. Plam, K. Hansen, and S. Burns. (In Mather, J. R., ed. Program abstracts, $75^{\text {th }}$ anniversary meeting of the Association of American Geographers, 1979. . . [Washington, D.C.], Association of American Geographers, p. 1 1 3.) 
Judson, A. 1970. Pilot study of weather, snow, and avalanche reporting for western United States. Canada. National Research Council. Associate Committee on Geotechnical Research. Technical Memorandum No. 98, p. 123-34.

Judson, A. 1975. Avalanche warnings: content and dissemination. U.S. Dept. of Agriculture. Forest Service. Research Note RM-291.

Knepper, D. H., jr. 1977. The applications of Landsat data to delimitation of aralanche hazards in mountain Colorado. Greenbelt, Md., Goddard Space Flight Center. (Final Report, NASA Contract No. NAS ${ }_{5-209}$ I $_{4}$.)

Krebs, P. V., ed. Unpublished. Evaluation of the snow avalanche hazard in the valley of Gore Creek, Eagle County, Colorado. [Institute of Arctic and Alpine Research, University of Colorado, report to the town of Vail, 1976. NASA-PY Grant No. NGL-06-003-200.]

LaChapelle, E. R., ed. 1974-75. Cascade Passes avalanche atlas. Pts. I and II. Report to Washington State Highway Dept. Seattle, Geophysics Program and Dept. of Civil Engineering, University of Washington. 2 vols.

Luedke, R. G. 1976. Map showing potential snow avalanche areas in the Telluride Quadrangle, San Miguel, Ouray, and San Juan counties, Colorado. U.S. Geological Survey. Map MF-8 r 9.

Mears, A. I. 1976. Guidelines and methods for detailed snow avalanche hazard investigations in Colorado. Colorado Geological Survey. Bulletin 38.

Mears, A. I. 1979. Colorado snow avalanche area studies and guidelines for avalanche-hazard planning. Colorado Geological Survey. Special Publication 7.

Miller, L., and others. 1976. Avalanche atlas, San Juan County, Colorado, by L. Miller, B. R. Armstrong, and R. L. Armstrong. University of Colorado. Institute of Arctic and Alpine Research. Occasional Paper No. 17.

Perla, R. I., and Martinelli, M., jr. 1976. Avalanche handbook. U.S. Dept. of Agriculture. Forest Service. Agriculture Handbook 489 .

Plam, M. Unpublished. Map of snow avalanche distribution and frequency. (Monarch Lake Quadrangle, Colorado, 7.5 minute series.) [MS., r979.]

Rogers, W. P., and others. 1974. Guidelines and criteria for identification and land-use controls of geologic hazard and mineral resource areas, by W. P. Rogers [and 7 others]. Colorado. Geological Survey. Special Publication 6.

Waterman, S. 1978. The application of Landsat data to mapping avalanche hazards. (In MacEwan, A., ed.

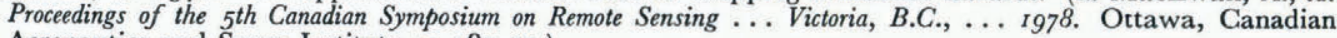
Aeronautics and Space Institute, p. 187-91.)

Williams, K. 1978. The Colorado avalanche warning program. Canada. National Research Council. Associate Committee on Geotechnical Research. Technical Memorandum No. 120, p. $116-31$. 